\title{
Pemekaran Daerah dan Terbentuknya Kelas Menengah (Baru) Papua
}

\author{
I Ngurah Suryawan \\ Fakultas Sastra dan Budaya Universitas Papua, Manokwari, Papua Barat \\ (e-mail: ngurahsuryawan@gmail.com)
}

\begin{abstract}
This article discusses the impact of territorial expansion on the socio-political structure among Papuans. The strategic issue of socio-economic and cultural transformation that is driven through territory expansion becomes hampered when new Papuan elites take over resources. The formation of a new social class, namely the new Papuan elites provided enormous political economy benefits in the expansion of the region. Strategic political positions and access toward development projects are tempting income. The presence of the new Papuan middle class is an important phenomenon in the midst of various development efforts for the welfare of the Papuan. Applying ethnographic approach this study aims to examine the process of the formation of Papuan elites as an impact of the dynamics of regional expansion, as well as the habitus of the presence of elites and strategy practiced in the community level.
\end{abstract}

Artikel ini mendiskusikan dampak dari pemekaran daerah terhadap struktur sosial politik di tengah masyarakat Papua. Isu strategis transformasi sosial ekonomi dan budaya yang digerakkan melalui pemekaran daerah menjadi terhambat saat para elit baru Papua mengambilalih sumber daya. Terbentuknya kelas sosial baru yaitu para elit baru Papua memberikan keuntungan ekonomi politik yang sangat besar dalam pemekaran daerah. Jabatan politik strategis dan akses proyek-proyek pembangunan menjadi pendapatan yang menggiurkan. Kehadiran kelas menengah baru Papua ini menjadi fenomena penting di tengah berbagai usaha pembangunan untuk kesejahteraan masyarakat Papua.Dengan menggunakan pendekatan etnografi kajian ini bertujuan untuk mengkaji tentang proses terbentuknya para elit Papua sebagai buah dari dinamika pemekaran daerah, serta habitus kehadiran para elit dan siasat yang mereka praktikkan di tengah masyarakat.

Keywords: middle class; the Papuan elite; social transformation; territory expansion 


\section{Pendahuluan}

Wacana pemekaran wilayah menjadi pembicaraan yang sangat menggairahkan di berbagai wilayah yang akan, sedang dan telah mengalami proses pemekaran. Papua Barat, yang dikenal sebagai wilayah kepala burung merupakan wilayah yang diprogramkan untuk pemekaran. Wacana mengenai pemekaran wilayah itu berkembang dan menjadi fokus pembicaraan di berbagai kalanga (Asosiasi Antropologi Indonesia (AAI) 2011; Brata 2008; Chauvel 2005; Hommers 2003; Suryawan 2013b). Para elit-elit lokal membicarakan masalah pemekaran wilayah dengan perspektif kepentingan para elit. Sementara itu para pegawai membicarakannya dengan perspektif "keamanan"nya sebagai pegawai pemerintah; pedagang membicarakan kemungkinan pengembangan usaha mereka, buruh pun membicarakan dalam perspektif kemungkinan perbaikan hidup mereka Prinsipnya semua level dalam struktur masyarakat terlibat dalam pembicaraan mengenai persoalan pemekaran daerah di kawasan kepala burung Papua (Suryawan 2011b, 2011a).

Tampaknya pergunjingan dan gosip politik yang tidak jelas ujung pangkalnya tentang pemekaran daerah menjadi candu yang menggiurkan sekaligus memabukkan, khususnya bagi para elit local dan secara pelan namun pasti menyebar hingga ke masyarakat luas di level akar rumput (Pamungkas 2004; Timmer 2007). Berita media-media massa pun membahas tentang pro dan kontra seputar wacana pemekaran daerah yang terus-menerus terjadi tanpa henti. Wacana pemekaran telah menjadi konsumsi publik dan menjadi penegasan bahwa perbincangan tentang politik menjadi hal yang dominan tentang Papua melebihi hal yang lain.

Beberapa bagian masyarakat dan elit lokal terus memperjuangkan pemekaran, sebagian elemen masyarakat lainnya justru menolaknya dengan berbagai alasan (Hommers 2003). Mulai dari membuka peluang migrasi para pendatang, ketersingkiran orang asli Papua di tanahnya sendiri, hingga korupsi ekonomi dan politik yang melibatkan para elit lokal Papua dan beberapa elemen masyarakat yang menjadi kolusinya. Cita-cita luhur pemekaran untuk mensejahterakan masyarakat seakan pelan namun pasti menjadi jauh dari harapan. Kesejahteraan rakyat telah dirampas oleh sebagian kelompok masyarakat dalam komunitas mereka sendiri.Intinya terjadi keterpecahan yang akut di tengah masyarakat antara yang berapi-api memperjuangkan pemekaran dan menolaknya karena akhirnya menjadi candu yang melumpuhkan (Ramstedt dan Thufail 2011; Scott 1995).

Pemekaran sendiri secara tekstual juga menjadi pembahasan yang ramai dalam ranah akademik. Makagansa (2008: 9) sebagai contoh menyatakan bahwa istilah pemekaran wilayah sebenarnya merupakan penghalusan bahasa (eufimisme) dari kata "perpisahan" atau "pemecahan" atas suatu wilayah tertentu yang kemudian membentuk suatu unit administrasi lokal yang baru. Jika dilihat dari perspektif keseimbangan, harmoni, maka pemekaran mengandung makna negatif. Oleh karena itu dalam konteks seperti ini istilah pemekaran. Dilihat dari filosofi harmoni, istilah perpisahan 
atau perpecahan memiliki makna yang negatif sehingga istilah pemekaran daerah dirasa lebih cocok digunakan untuk menggambarkan proses terjadinya daerah daerah otonom baru pasca reformasi di Indonesia.

Pemekaran daerah, yaitu pemisahan diri suatu daerah dari induknya yang mempunyai tujuan untuk mendapatkan status yang lebih tinggi dan meningkatkan pembangunan daerah. Sebagai contoh, pemekaran daerah dapat meningkatkan status kekuasaan, pemekaran daerah juga dapat memperbesar peluang menjadi PNS, dengan adanya otonomi daerah memungkinkan sebagian orang menikmati kas daerah, selain itu juga pemekaran daerah dapat menggali setiap potensi kebudayaan atau sumber daya alam dari setiap daerah atau provinsi masing-masing (Giay 2000). Selain itu pemekaran daerah semestinya mempertimbangkan aspek budaya dengan berbagai tradisi yang hidup di dalam masyarakat (Flassy 1995; Giay 1996; Henley, Davidson, dan Moniaga, ed. 2010), karena tanpa pertimbangan-pertimbangan tersebut akan terjadi berbagai gejolak sosial budaya, selain politik tentu saja.

J. Kaloh (2007: 12) lebih lanjut mengatakan bahwa dalam konteks pemekaran daerah/ wilayah tersebut yang lebih dikenal dengan pembentukan daerah otonom baru, bahwa daerah otonom tersebut diharapkan mampu memanfaatkan peluang yang lebih besar dalam mengurus dirinya sendiri, terutama berkaitan dengan pengelolaan sumbersumber pendapatan asli daerah, sumber daya alam, dalam rangka meningkatkan ke- sejahteraan dan pelayanan kepada masyarakat setempat yang lebih baik. Asumsi dasar dari orientasi pemekaran wilayah ini adalah dengan terbaginya wilayah maka memungkinkan terfokusnya pembangunan wilayah. Hal ini berkait dengan keluhan yang selama ini muncul bahwa dalam sebuah wilayah administratif selalu muncul istilah wilayah utama (focused region) dan wilayah pinggiran (perifer area).

Pemekaran daerah adalah suatu proses membagi satu daerah administratif (daerah otonom) yang sudah ada menjadi dua atau lebih daerah otonom baru berdasarkan Undang-Undang Nomor 23 Tahun 2014 tentang Pemerintahan Daerah. Landasan pelaksanaannya didasarkan pada Peraturan Pemerintah Nomor 78 Tahun 2007 tentang Tata Cara Pembentukan, Penghapusan, dan Penggabungan Daerah. Kedua peraturan itulah yang menjadi landasan dilaksanakannya pemekaran wilayah di Indonesia. Problematika yang muncul kemudian adalah bahwa dengan keragaman budaya masyarakat Indonesia maka menjadikan keragaman problematika yang muncul, termasuk di antaranya adalah konflik agama (Suryawan 2017) yang disebabkan oleh dinamika sosial yang muncul akibat mobilitas sosial antar daerah akibat adanya pemekaran wilayah tersebut

Beberapa kajian tentang pemekaran daerah yang relevan untuk kajian ini antara lain kajian dari Paulus L. Hommers (2003) yang dalam kajiannya menjelaskan adanya kontroversi dari berbagai kelompok dalam masyarakat Papua. Kontroversi itu tidak hanya berkait dengan pro 
dan kontra, namun juga berkait dengan menjadi berapa wilayah semestinya Papua itu dibagi. Sebagian kelompok masyarakat menegaskan agar Papua dibagi menjadi tiga wilayah, dan kelompok yang lain menyatakan bahwa sebaiknay Papua dibagi menjadi tujuh wilayah. Pembagian tersebut didasarkan pada kondisi alam serta keragaman budaya Papua yang sangat tinggi. Sebagaimana dikaji oleh Ahmad Kadir (2017) yang menyatakan tentang tingginya keragaman budaya Papua yang memungkinkan keragaman problematika sosial budaya sehingga mensyaratkan keragaman dalam pengelolaan pembangunan.

Kajian I Ngurah Suryawan (2011b) mengenai dinamika otonomi khusus dan pemekaran wilayah di Papua menemukan adanya kontestasi antar elit lokal dengan munculnya wilayah-wilayah baru. Dominasi kontestasi identitas lokal dan latar belakang budaya masuk ke dalam pusaran kontestasi politik lokal. Dengan fokus kajiannya di Manokwari Suryawan menemukan adanya manipulasi identitas budaya demi untuk memperoleh posisi elit dalam politik. Temuan Suryawan sejalan dengan temuan Jacqueline Vel dalam penelitiannya di Sumba bahwa proses demokrasi di Indonesia, dengan berbagai dinamika otonomi daerah telah menghidupkan kembali rivalry tradisional yang dalam beberapa dekade tidak tampak. Hal ini karena suasana rivalry dalam proses demokrasi telah menstimulir rasa persaingan yang telah lama tertanam secara budaya.

Dengan pendekatan etnografi, penelitian ini menggunakan observasi dan wawancara mendalam dalam pengumpulan datanya. Fokus perhatian dari penelitian ini adalah pada perilaku para elit Papua di tengah masyarakat. Wawancara mendalam dilakukan untuk mendapatkan informasi tentang motivasi dan tujuan yang diinginkan oleh para elit dalam praktik-praktik yang mereka lakukan. Keseluruhan data-data tersebut dituliskan dengan metode etnografi yang menekankan pada deskripsi data-data di lapangan. Sebagai ciri etnografi, maka data dipaparkan dalam bentuk emic yang kemudian dianalisis secara etic (Spradley 1997). Metode emic adalah metode pemaparan data sesuai dengan cara informan mengatakan, dengan perspektif informan, sementara metode etic adalah metode pemaparan dengan cara penulis memaparkan, dengan menggunakan metode akademik.

Berdasarkan beberapa pembahasan di atas, artikel ini memfokuskan perhatiannya pada proses terbentuknya para elit Papua sebagai buah dari dinamika pemekaran daerah. Pertanyaan penelitian ini penting karena kehadiran para elit yang menjadi kelompok kelas menengah baru di Papua ini sangat berpengaruh besar dalam rangka perubahan sosial yang dicita-citakan di Papua. Artikel ini juga akan menbahas tentang habitus kehadiran para elit dan siasat yang mereka praktikkan di tengah masyarakat. Kelompok kelas menengah baru ini memainkan peranan yang sangat penting diantara memenuhi keinginan negara dan kekuasaan serta berjanji untuk kesejahteraan masyarakatnya.

\section{Proses Terbentuknya Elit Baru Papua}

Jika menelisik ke belakang, sejarah pemekaran di Tanah Papua berawal dari ter- 
pecahnya Provinsi Irian Jaya menjadi Irian Jaya Barat (kini bernama Provinsi Papua dan Papua Barat). Berdirinya provinsi baru yang nama sebelumnya adalah Irian Jaya Barat berawal dari dialog antara tokoh-tokoh masyarakat Irian Jaya Barat dengan pemerintah Indonesia pada 16 September 2002. Para tokoh-tokoh masyarakat Papua ini menyampaikan agar Menteri Koordinator Politik dan Keamanan dan Menteri Dalam Negeri segera mengaktifkan kembali Provinsi Irian Jaya Barat yang sudah ditetapkan pad 12 Oktober 1999. Provinsi Irian Jaya Barat didirikan berdasarkan Undang-Undang No. 45 Tahun 1999 dan dipercepat dengan Instruksi Presiden (Inpres) No. 1 Tahun 2003. Peresmian Kantor Gubernur Irian Jaya Barat dilakukan oleh Pejabat Gubernur Abraham Oktavianus Ataruri yang berlangsung pada 6 Februari 2003.

Terbentuknya kabupaten baru di Provinsi Papua Barat seperti Kaimana, Teluk Wondama, Sorong Selatan, Maybrat, dan dua yang terbaru yaitu Manokwari Selatan dan Pegunungan Arfak menggambarkan begitu bergairahnya keberlangsungan pemekaran daerah di wilayah Provinsi Papua Barat (Widjojo 2001). Di tengah diversitas budaya yang tinggi di wilayah vogelkop (kepala burung) ini (Kadir 2017) selalu muncul keinginan untuk memecah wilayah kembali dalam bentuk kabupatenkabupaten baru (Prakarsa Rakyat 2007). Demam pemekaran sangat jelas terlihat dari keinginan beberapa elemen rakyat Papua untuk memekarkan daerahnya menjadi 33 DOB (Daerah Otonom Baru). Dari 10 DOB adalah hasil pemekaran di Provinsi Papua
Barat. Hal ini sangat mencengangkan sekaligus mengundang keprihatinkan akan proses dan dampakyang akan terjadi di kemudian hari.

Di tengah demam pemekaran daerah itulah muncul kelompok-kelompok di tengah masyarakat yang menjadi otak dan berada di lapisan atas dari kelompok pejuang pemekaran (Suryawan 2013c). Jika kita menelisik jauh ke belakang, kelompok-kelompok sosial politik ini adalah kumpulan orang-orang yang mempunyai pengaruh di tengah masyarakat maupun jaringan ke lingkaran kekuasaan negara maupun aparat keamanan. Orang-orang yang berpengaruh ini mempunyai modal sosial (tokoh agama, adat, politik, birokrat) dan modal ekonomi (pengusaha, pejabat, tuan tanah) sehingga sangat berpengaruh di tengah masyarakat. Kelompok orang-orang berpengaruh inilah yang sering disebut dengan "orang-orang kuat" lokal yang memainkan peranan sebagai broker (perantara) antara kepentingan kekuasaan dan masyarakat. Kelompok ini tidak akan pernah rugi karena orientasi-nya adalah menghisap kedua kelompok yang berusaha dijembataninya (Suryawan 2013a).

Terbentuknya "orang-orang kuat" yang memiliki kuasa dan pengaruh di Tanah Papua tidak bisa dilepaskan dari restrukturisasi (penyusunan/konsolidasi kembali) kekuasaan Orde Baru pasca bergabungnya (integrasi/ aneksasi?) Papua ke dalam pangkuan Negara Kesatuan Republik Indonesia (NKRI). Dalam rentang waktu tahun 1970-2000-an, telah terjadi konsolidasi kekuasaan yang dilakukan oleh negara dengan introduksi birokrasi pemerintahan dan pola berpikir "pembangunan- 
isme"-dimana stablitas keamanan menjadi harga mati untuk terlaksananya programprogram negara di seluruh Tanah Papua.

Di tengah situasi itulah terlahir kelompokkelompok elit Papua di pemerintahan yang membawa pengaruh besar terhadap kelompok elit di tengah masyarakat Papua sendiri. Klasifikasi dari Mansoben (1994) tentang Sistem Politik Tradisonal di Irian Jaya - yang menyebutkan tipe kepemimpinan terdiri dari pria berwibawa, tipe kepemimpinan raja, tipe kepemimpinan kepala suku atau kepala klen, dan sistem pemerintahan adat dengan tipe kepemimpinan campurantentunya mengalami perubahan dan kondisi yang semakin rumit seiring pengaruhpengaruh modernitas yang terjadi di tengah masyarakat Papua.

Basis pengaruh dan kekuasaan bagi sistem kepemimpinan tradisional, yang salah satunya diungkapkan oleh Mansoeben, diantaranya adalah penguasaan kepada jaringan relasi (hubungan) yang terbangun di tengah masyarakat secara sederhana, dimana terdapat sejumlah nilai, norma dan aturan yang bersumber dari kebudayaan setempat. Di tengah relasi inilah para pemimpin lokal bertugas mengatur keseharian hidup dari masyarakat setempat dengan berbagai modal-modal yang telah mereka miliki, seperti modal sosial (sebagai pria berwibawa yang mempunyai banyak babi, tanah, dan lainnya), budaya (pewaris dari keturunan raja, kepala suku atau klen). Dengan memiliki kelebihan modal sosial dan budaya, ditambah dengan modal materi, para pemimpin lokal Papua ini kemudian mentautkan (menghubungkan) dirinya dengan dunia global dengan berbagai kemungkinankemungkinan dan sudah tentunya dengan berbagai kepentingan (Zollner 2006).

Fragmentasi (keterpecahan) justru terjadi di tengah situasi perubahan sosial yang sedang dialami oleh Papua. Mengidentifikasi dan membaca dinamika "orang-orang kuat" lokal menjadi begitu sumir namun dampaknya terasa jelas dalam setiap praktik-praktik pembanguan dan kekuasaan di Tanah Papua. Penggunaan perspektif tradisional tentang kepemimpinan seperti yang diungkapkan Mansoben (1994) beresiko gagal untuk menangkap kompleksitas dan dinamika yang dipentaskan para orang kuat lokal ini yang terus-menerus bergerak. Namun yang pasti, lahirnya orang-orang kuat lokal Papua mencerminkan berhasilnya pengaruh negara Indonesia dalam memfasilitasi berbagai peluang-peluang tempat hidup dan berkembangnya para orang-orang kuat lokal ini.

Salah satu sumber kehidupan orang lokal ini adalah di sumber-sumber daya di pemerintahan, yang justru dikelola oleh negara itu sendiri, dan kongsi-kongsi (persekutuan) dalam mengeksploitasi sumber daya alam (Zollner 2006). Kedua sumber daya ini menjadi lahan hidup para orang-orang kuat lokal yang melakukan kontrol dan penguasaan terhadap sumber daya tersebut dan menciptakan jaringan-jaringan di tengah birokrasi pemerintahan dan korporasi perusahaan multinasional.

Bekerjanya orang-orang kuat lokal ini juga menyasar (dan menggunakan) modal budaya 
dan sosial tradisional yang dimiliki oleh pria berwibawa, raja, kepala suku, dan kepala klan. Namun satu hal cerdas yang dilakukannya adalah mengapropriasi (meminjam atau mengambil alih untuk kepentingan sendiri) modal sosial dan budaya tradisional untuk "dimanfaatkan" demi berbagai kepentingan. Hal ini biasanya sering dapat dilihat ketika investasi global dalam wujud perusahaanperusahaan masuk ke kampung-kampung (Lounela dan Zakaria 2002). Pada saat inilah jaringan orang-orang kuat lokal di pemerintahan dan masyarakat lokal tempat rencana investasi tersebut berlangsung memainkan pengaruhnya untuk kepentingannya sendiri.
Dalam perbincangan yang lebih luas, orang kuat lokal dalam bahasa Migdal (dalam Sidel 2005: 73) berhasil melakukan "kontrol sosial" yang efektif pada negara-negara dunia ketiga yang sedang berkembang. Orang-orang kuat lokal ini berhasil menempatkan diri atau menaruh anggota keluarga mereka pada sejumlah jabatan penting demi menjamin alokasi sumber-sumber daya berjalan sesuai dengan aturan mereka sendiri ketimbang menurut aturan-aturan yang dilontarkan dalam retorika resmi, pernyataan kebijakan, dan peraturan perundang-undangan yang dibuat di ibukota atau oleh pelaksana peraturan yang kuat.

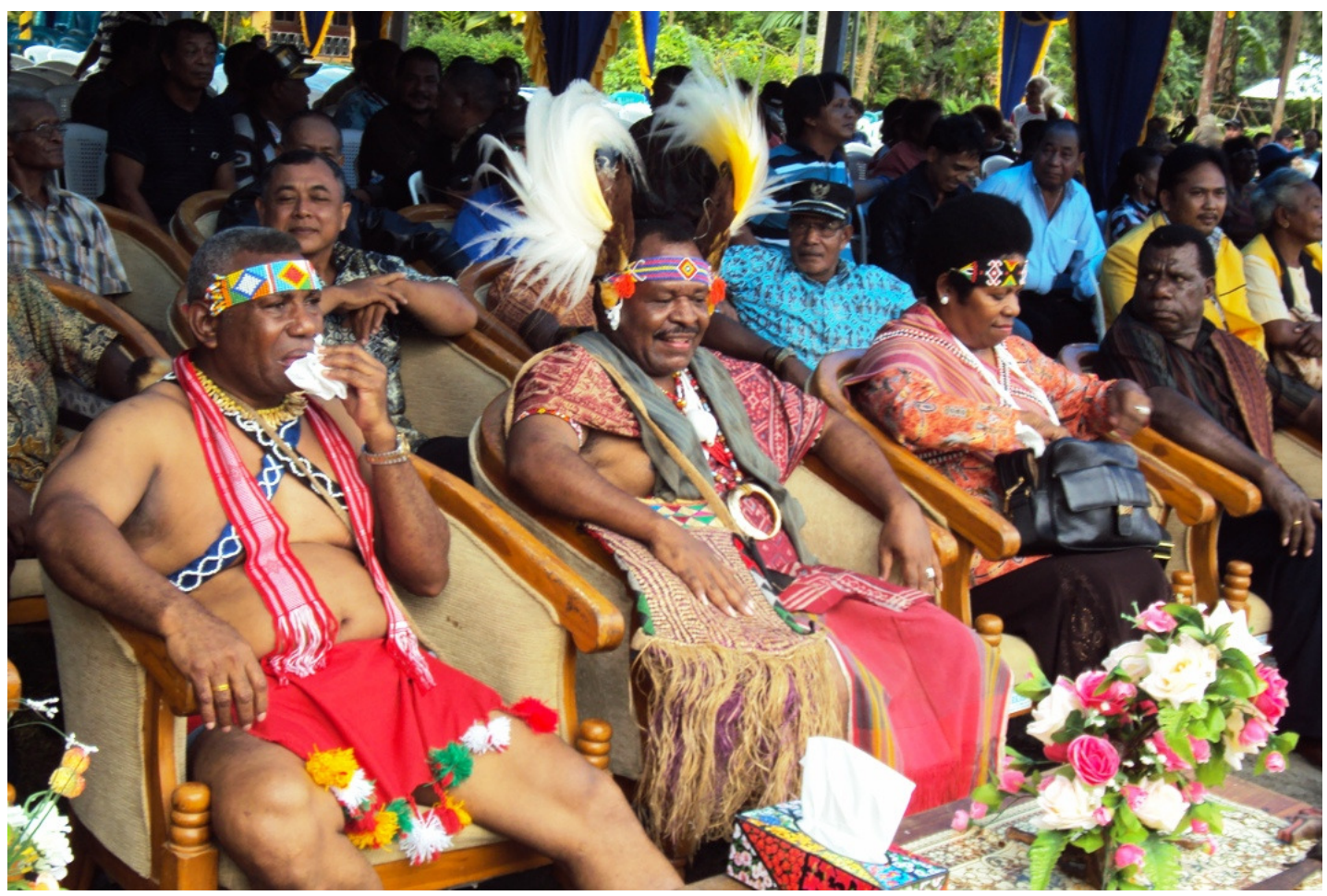

Gambar 1

Para elit Papua sedang mengikuti acara deklarasi pencalonan diri sebagai Gubernur dan Wakil Gubernur Papua Barat (foto: I Ngurah Suryawan) 
Orang kuat lokal meskipun terkesan menjadi "penghambat" lajunya pemerintahan, tapi sesungguhnya bertindak sebagai pelayan pertumbuhan ekonomi, memfasilitasi pengalihan tanah dan penindasan buruh serta memungut keuntungan sangat besar sebagai pialang lahan dan sektor bangunan. Para mafia lokal di Indonesia juga mengawasi industri di kotakota besar dan penggalian sumber daya alam kehutanan dan pertambangan yang berlimpah di seluruh nusantara. "Orang kuat lokal" yang sering diremehkan sebagai musuh pembangunan akhirnya lebih tampak sebagai agen terdepan perkembangan kapitalis yang tidak diakui (Sidel 2005: 102).

Para orang kuat lokal inilah yang sebenarnya menjadi pemain dibelakang layar dari berjalannya proses pembangunan dan pemekaran daerah di Tanah Papua. Kelahirannya para orang kuat lokal ini sebagai kelompok elit Papua tidak bisa dilepaskan dari kehadiran beragam bentuk struktur-struktur ataupun sistem-sistem yang pada intinya bertujuan untuk mengkoloni (baca: menjajah) Tanah Papua. Beragam struktur dan sistem tersebut lambat laun menciptakan kelompok masyarakat yang sangat dekat dan mempunyai akses yang mudah kepada kelompok-kelompok kekuasaan maupun akses kepada moda ekonomi baru (kuasa investasi global). Selain itu, struktur pemerintahan, birokrasi, pendidikan, dan kelompok swasta lainnya merupakan sistem yang menciptakan kelompok-kelompok kelas menengah baru dalam masyarakat. Kelompokkelompokinilah yang berada pada struktur ma- masyarakat kelas atas yang mempunyai kekuatan modal untuk berkongsi dengan negara (baca: pemerintahan dan apaturnya) dan membentuk jaringan kapital dan kekuasaan.

Dalam konteks yang terjadi di Tanah Papua, bertumbuh kembangnya struktur kekuasaan yang dibentuk oleh pemerintah Indonesia hingga kini terasa kuat mencengkram kebebasan masyarakat dalam berekspresi, sekaligus mempengaruhi pola berpikir masyarakat. Masyarakat Papua sebagai pelaku sosial sangat terpengaruh dengan rangkaian sistemsistem dan struktur pemerintahan, bahkan berusaha memanfaatkan peluang-peluang yang disediakan oleh sistem dan struktur tersebut untuk mengambil keuntungan pribadi atau kelompok etniknya. Dalam konteks inilah memahami kelahiran kelompok elit dalam kelas menengah baru di Papua tidak cukup hanya melihat sistem dan struktur yang membentuknya, atau peranan dari agen-agen dalam masyarakat saja. Argumentasi lainnya melihat bahwa terjadi dialektika antara pelaku dan sistem. Struktur-struktur sosial hanya bisa diciptakan, dilanggengkan, dan diubah oleh pelaku-pelaku sosial; sebaliknya, pelaku sosial kendati dikatakan bebas, dikondisikan oleh struktur-struktur tersebut. Dalam konteks itu, menjadi mudah untuk dipahami proses lahirnya kelompok elit sebagai kelas menengah baru di Papua yang terjadi marak belakangan ini. Mereka inilah kelompok kelas menengah yang memiliki jejaring kuat dengan berbagai kelompok elit di pusat kekuasaan serta memiliki investasi besar di beberapa real eatate di Pulau Jawa. 


\section{Habitus Kehadiran Para Elit dan Siasat yang Mereka Praktikkan di Tengah Masyarakat}

Kehadiran kelompok masyarakat elit kelas menengah baru di Papua tidak terlepas dari relasi (hubungan) yang tercipta antara pelaku (manusia sendiri) dengan lingkungannya yang berlangsung lama dan berubah-ubah. Dari proses hubungan itulah tercipta struktur subjektif yang yang terbentuk dari pengalaman individu berhubungan dengan individu lain dalam jaringan struktur objektif (struktur/ sistem) yang ada dalam ruang sosial" (Takwin ed. 2005: xvii). Pierre Bourdieu (1930-2002) adalah sosiolog Prancis yang memperkenalkan konsep habitus untuk menjebatani perdebatan tentang analisis struktur dan agensi dalam memahami fenomena sosial yang terjadi di tengah masyarakat.

Habitus bisa dikatakan sebagai ketidaksadaran kultural, yakni pengaruh sejarah yang secara tak sadar dianggap alamiah. Habitus adalah produk sejarah yang terbentuk setelah manusia lahir dan berinteraksi dengan masyarakat dalam ruang dan waktu tertentu. Jelas habitus bukan kodrat, bukan bawaan alamiah yang melengkapi manusia, baik secara psikologis maupun biologis. Habitus merupakan hasil pembelajaran lewat pengasuhan, aktivitas bermain, dan juga pendidikan masyarakat dalam arti luas. Pembelajaran itu terjadi secara halus, tak disadari dan tampil sebagai hal wajar, sehingga seolah-olah sesuatu yang alamiah, seakan-akan terberi oleh alam atau "sudah ada dari sananya" (Takwin ed. 2005: xviii-xix). Habitus adalah kerangka penafsiran untuk memahami dan menilai realitas sekaligus penghasil praktik-praktik kehidupan yang sesuai dengan struktur-struktur objektif. Kedua hal tersebut tidak bisa dipisahkan. Habitus menjadi dasar kepribadian individu. Pembentukan dan berfungsinya habitus seperti lingkaran yang tidak diketahui ujung pangkalnya: di satu sisi, sangat memperhitungkan hasil dari keteraturan perilaku dan di lain sisi modalitas praktiknya mengandalkan pada improvisasi, dan bukan pada kepatuhan pada aturan-aturan (Haryatmoko 2003: 10).

Salah satu yang membentuk habitus elit Papua adalah "panggung-panggung" yang disediakan oleh negara yaitu dalam bentuk introduksi (birokrasi) pemerintahan yang membentuk kelas menengah Papua yang terdiri dari para pejabat dan barisan aparat birokrasi pemerintahan. Introduksi agamaagama samawi yang masuk ke Papua juga menghasilkan para elit agama dengan tujuan "memberadabkan" bangsa Papua. Para elit birokrasi juga (seolah-olah) mempunyai tujuan untuk melayani rakyat Papua dalam menjalankan pembangunan dan untuk kemajuan dan kesejahteraan rakyat. Belum lagi dengan masuknya investasi dalam bentuk perusahaanperusahaan multinasionasional dalam wujud perusahaan-perusahaan yang merambah kampung-kampung dan mengeruk kekayaan alam di Tanah Papua (Tsing 2005). Di tengah struktur-struktur sosial itulah terbentuk para elit Papua yang menikmati keuntungan struktur agama, ekonomi, dan politik tersebut.Mereka membentuk dirinya "lepas" dari akar rakyat Papua kebanyakan dan menjadi kelompok masyarakat kelas menengah yang selalu di- 
pertanyakan komitmennya bagi gerakan perubahan sosial di Tanah Papua.

Salah satu habitus yang merubah-dan juga merumitkan—secara drastis kebudayaan dan identitas bangsa Papua adalah hadirnya pembangunan dengan mimpi kemajuaan dan sekaligus memberadabkan rakyat Papua. Namun situasi yang terjadi justru sebaliknya.

Mengutip Walter Benjamin (1892-1940) yang mengkritik pendangan masyarakat modern bahwa kemajuan dan peradaban modern itu menjanjikan kebahagian masa depan. Dalam konteks Papua, ideologi dan kebijakan pembangunan di atas kertas menjanjikan masa depan yang wah. Tetapi dalam kenyataannya di lapangan, ia berubah wajah menjadi ideology yang membenarkan perampasan tanah, pengusiran warga masyarakat, "peternakan" OPM (Organisasi Papua Merdeka) dan GPK (Gerakan Pengacau Keamanan), pembunuhan, penghancuran identitas dan masa depan bangsa Papua. Benjamin pesimis terhadap kebudayaan modern yang memacu manusia untuk mengejar pengusaan ilmu pengetahuan dan teknologi dan penemuan-penemuan baru di segala bidang kehidupan manusia untuk men-

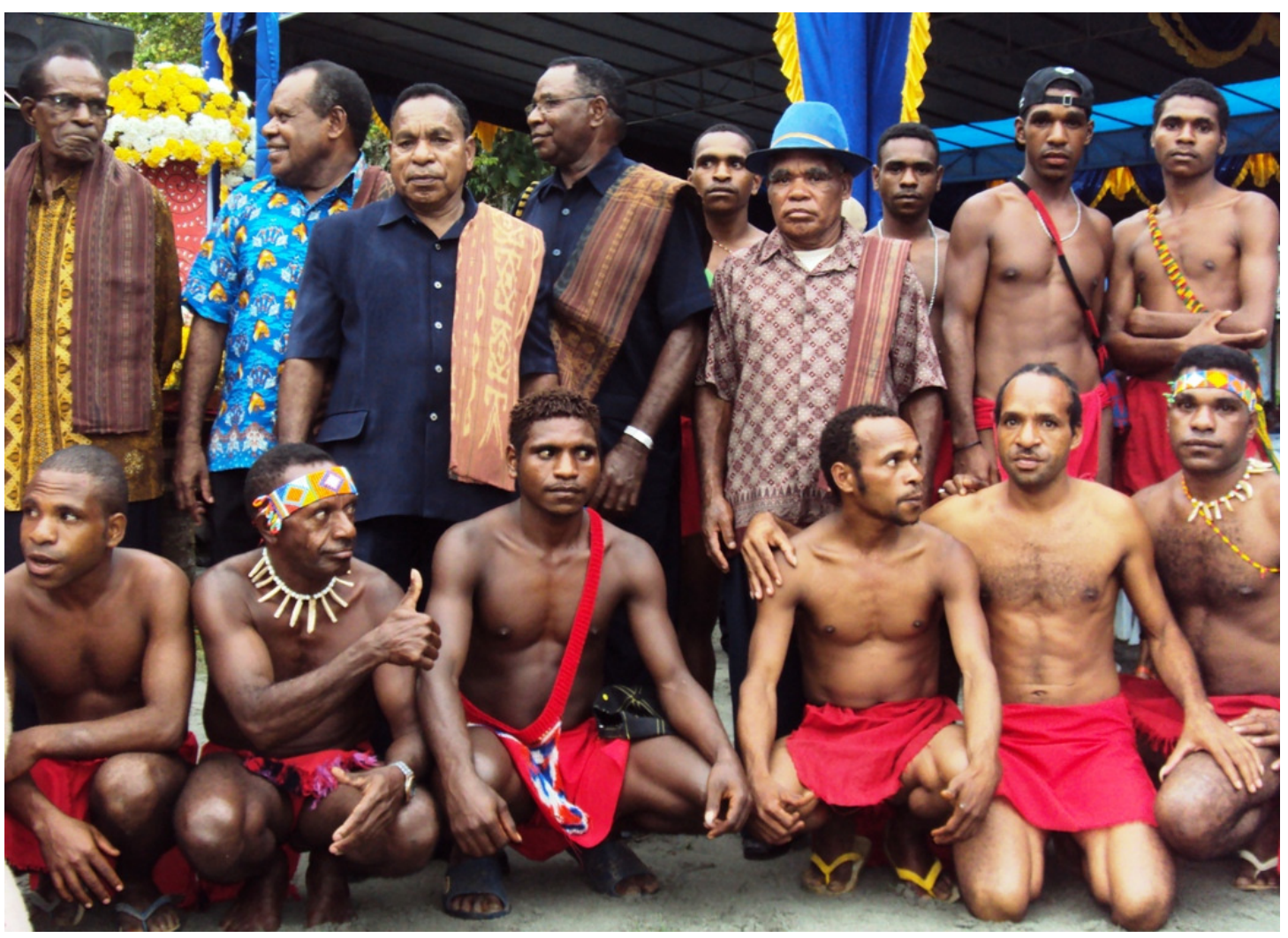

Gambar 2.

Masyarakat Suku Arfak di daerahPegunungan Arfak Manokwari, Papua Barat bersama dengan para elitnya (foto: I Ngurah Suryawan) 
capai kesempurnaan dan kebahagiaan. Karena bagi Benjamin, usaha menguasai ilmu pengetahuan dan teknologi ini hanya mitos dan janji utopis masa depan yang tidak seluruhnya benar. Karena obsesi terhadap kemajuan tidak saja merusak hubungan manusia dengan manusia dalam kehidupan sosial, tetapi juga mengatur kehidupan manusia itu sendiri. Lebih tragis lagi pengejaran terhadap kemajuan itu membawa kehancuran dan pemusnahan bagi pihak lain dan bagi kemanusiaan itu sendiri (Giay 2000).

\section{Kesimpulan}

Pemekaran wilayah yang terjadi di Papua tidak dapat dilepaskan upaya pembangunan wilayah Indonesia dengan tujuan kemakmuran dan kesejahteraan masyarakat di mana proses pemekaran wilayah dijalankan. Fenomena pemekaran secara gamblang memaparkan bagaimana lokalitas kekuasaan begitu nyata terjadi. Pembagian wilayah-wilayah berdasarkan alasan etnik bahkan kekerabatan tidak terhindarkan. Di tengah situasi pemekaran di Papua, muncul pertanyaan kritis mengenai kemungkinan bagi orang Papua untuk mengembangkan identitas-identitas baru yang lebih inklusif bukan ekslusif berbasis etnik atau bahkan marga tertentu.

Memikirkan untuk mengembalikan Papua ke titik asli budaya-budaya etnik di tengah interkoneksi global akan "mengkolonisasi" Papua menjadi wilayah eksotik, steril, dan tanpa sejarah. Padahal budaya Papua seharusnya dinamik dan menyejarah dan tidak terisolasi dari perkembangan dunia. Tapi, apakah pe- mekaran memungkinkan untuk lahirnya apresiasi terhadap pembaharuan-pembaharuan kebudayaan yang melampaui etnik-etnik? Itulah letak persoalan dan tantangannya.

Pemekaran daerah adalah ruang dimana terjadi friksi (persentuhan) antara kebudayaan etnik dan introduksi kebudayaan luar.Dalam merespon friksi inilah orang Papua ditantang untuk berpikir dan mengembangkan pemikirannya untuk melahirkan kreatifitas-kreatifitas baru yang memungkinkan rakyat Papua memperoleh akses, ruang, dan ekspresi guna selalu memperbaharui identitas dan kebudayaannya. Tantangan pemekaran daerah adalah melawan pemikiran untuk mengembalikan identitas dan kebudayaan Papua ke titik asali tempo dulu. Ruang-ruang interkoneksi yang terjadi pada pemekaran inilah sebenarnya kesempatan rakyat Papua untuk memikirkan identitas dan kebudayaannya yang baru, yang akan terus bergerak dinamis, menyejarah.

Pemekaran daerah juga menjadi salah satu struktur sosial yang menciptakan para kelas menengah baru ini. Lewat struktur-struktur sosial dalam pemekaran daerah itulah-dan tentunya masih banyak lagi yang lainnyahabitus kelas menengah Papua terbentuk. Mereka "membantinkan" dan menyatukan dirinya terhadap lingkungan-lingkungan sosial yang tanpa sadar membentuk cara berpikir dan berperilaku. Habitus kelas menengah Papua memunculkan para elit lokal yang justru "merampok" kedaulatan rakyat Papua untuk merubah diri dan lingkungan Papua ke arah yang lebih baik. Kasus-kasus korupsi yang dilakukan oleh para elit Papua, "pencurian" harkat dan martabat rakyat Papua dalam 
berbagai kasus-kasus perampokan sumber daya alam, penipuan melalui program-program pembangunan yang (katanya) mensejahterakan rakyat secara gambling menggambarkan bagaimana habitus kelas menengah telah menciptkan kelompok para elit yang telah merampok kedaulatan rakyat Papua sendiri untuk "memimpin diri mereka sendiri dalam gerakan pembebasan (perubahan) sosial di Tanah Papua". Di sanalah identitas Papua itu terus-menerus akan dipikirkan, dikonstruksi, dan diperdebatkan. Dengan demikian Papua menjadi hidup dan spirit yang akan terus menyala bagi generasi-generasi berikutnya di tanah yang diberkati ini.[]

\section{Daftar Pustaka}

Asosiasi Antropologi Indonesia (AAI). 2011. "Masih Ada Dusta di Antara Kita: Catatan Kritis Asosiasi Antropologi Indonesia Menuju Papua yang Damai."

Brata, Aloysius Gunadi. 2008. "Pemekaran Daerah di Papua: Kesejahteraan Masyarakat vs. Kepentingan Elit." dalam Simposium Nasional Riset dan Kebijakan Ekonomi: "Dampak Bencana Alam dan Lingkungan terhadap Pengelolaan Ekonomi Indonesia", 20-21 Agustus 2003. Surabaya: Departemen Ilmu Ekonomi Fakultas Ekonomi Universitas Airlangga. Retrieved (https://www.researchgate. net/publication/23991624_Pemekaran _Daerah_di_Papua_Kesejahteraan_Masy arakat_vs_Kepentingan_Elit).

Chauvel, Richard. 2005. Constructing Papua Nationalism: History, Ethnicity and Adaptation. Washington: East-West Center.
Flassy, Don. 1995. Pembangunan Berwawasan Identitas, Sebuah Tuntutan di Irian Jaya. Jayapura: Irian Jaya Studies.

Giay, Benny. 2000. Menuju Papua Baru: Beberapa Pokok Pikiran sekitar Emansipasi Orang Papua. Jayapura: Deiyai/Els-ham Papua.

Giay, Benny. 1996. "Pembangunan Irian Jaya dalam Perspektif Agama, Budaya, dan Antropologi." dalam Simposium Masyarakat dan Pembangunan di Daerah Irian Jaya. BPC GMKI Jayapura.

Haryatmoko. 2003. Etika Politik dan Kekuasaan. Jakarta: Kompas.

Henley, David, Jamie Davidson, dan Sandra Moniaga, ed. 2010. Adat dalam Politik Indonesia. Jakarta: KITLV Jakarta dan Yayasan Obor Indonesia.

Hommers, Paulus Louis. 2003. "Kontroversi dalam Kasus Pemekaran Provinsi di Papua." Jurnal Ilmu Sosial 1(3).

Kadir, Akhmad. 2017. "Melihat Indonesia dari Jendela Papua: Kebinekaan dalam Rajutan Budaya Melanesia." JSW: Jurnal Sosiologi Walisongo 1(2): 225-46. Retrieved (http://journal.walisongo.ac.id/index. php/JSW/article/view/2034).

Kaloh, J. 2007. Mencari Bentuk Otonomi Daerah: Suatu Solusi dalam Menjawab Kebutuhan Lokal dan Tantangan Global. Jakarta: Rineka Cipta.

Lounela, Anu dan R. Yando Zakaria, ed. 2002. Berebut Tanah: Beberapa Kajian Berperspektif Kampus dan Kampung. Yogyakarta: Insist, Jurnal Antropologi Indonesia dan Karsa.

Makagansa, H. R. 2008. Tantangan Pemekaran Daerah. Yogyakarta: FusPad. 
Mansoben, Johsz. R. 1994. Sistem Kepemimpinan Tradisional Irian Jaya. Jakarta: LIPI.

Pamungkas, Cahyo. 2004. "Konflik Elit Lokal dalam Pembentukan Provinsi Irian Jaya Barat." Jurnal Masyarakat Indonesia 30(1).

Ramstedt, Martin dan Fadjar Ibnu Thufail, ed. 2011. Kegalauan Identitas: Agama, Etnisitas, dan Kewarganegaraan pada masa Pasca-Orde Baru. Jakarta: PSDR LIPI, Max Planck Institute for Social Anthropology dan Grasindo.

Scott, James C. 1995. State Simplifications, Some Applications to Southeast Asia. Amsterdam: CASA.

Sidel, John T. 2005. "Bossism and Democracy in the Philippines, Thailand, and Indonesia: Towards an Alternative Framework for the Study of Local Strongmen." pp. 51-74 dalam Politicising Democracy: the New Local Politics of Democratisation. International Political Economy Series, ed. J. Harriss, K. Stokke, dan T. Olle. Basingstoke: Palgrave Macmillan.

Spradley, James. 1997. Metode Etnografi. terj. M. Z. Elizabeth. Yogyakarta: PT. Tiara Wacana.

Suryawan, I. Ngurah. 2011a. "Antropologi Gerakan Sosial: Membaca Transformasi Identitas Budaya di Kota Manokwari, Papua Barat." Jurnal Humaniora 23(3): 290-300. Retrieved (https://journal. ugm.ac.id/jurnal-humaniora/article/ view/1030).

Suryawan, I. Ngurah. 2013a. "Identifying the Dynamics and Complexities of Dewan Adat Papua (Papuan Customary Council): Cultural Identities and Responses." dalam Local Civil Societies Dynamics in Indonesia, ed. P. M. Laksono, Sukamdi, dan L. Schaupen. Yogjakarta, Netherland: CIDIN Radboud University Nijmegen The Netherlands dan UGM Yogyakarta.

Suryawan, I. Ngurah. 2011b. "Komin Tipu Komin': Elit Lokal dalam Dinamika Otonomi Khusus dan Pemekaran Daerah di Papua." Jurnal Ilmu Sosial dan Ilmu Politik 15(2):140-53. Retrieved (https://jurnal.ugm.ac.id/jsp/article/vie $\mathrm{w} / 11390 / 0)$.

Suryawan, I. Ngurah. 2017. "Lahirnya Zaman Bahagia: Transformasi Teologi Pribumi di Tanah Papua." JSW: Jurnal Sosiologi Walisongo 1(1): 121-34. Retrieved (http://www.journal.walisongo.ac.id/in dex.php/JSW/article/view/1939).

Suryawan, I. Ngurah. 2013b. "Siasat Rakyat di Garis Depan Global: Politik Ruang Pasar dan Pemekaran Daerah di Tanah Papua." Kritis: Jurnal Studi Pembangunan Interdisipliner 22(1):62-76.

Suryawan, I. Ngurah. 2013c. "Tanah Dibutuhkan Tapi Orang Tidak: Transformasi Masyarakat Adat dalam Perspektif Etnografi dan Sejarah Sosial." Kritis: Jurnal Studi Pembangunan Interdisipliner 22 (2).

Takwin, Bagus. 2005. "Proyek Intelektual Pierre Bourdieu: Melacak Asal-Usul Masyarakat, Melampaui Oposisi Biner dalam Masyarakat." dalam (Habitus $x$ Modal) + Ranah = Praktik, ed. Harker, dkk. Yogyakarta: Jalasutra.

Timmer, Jaap. 2007. "Desentralisasi Salah Kaprah dan Politik Elit di Papua." dalam Politik Lokal di Indonesia, ed. H. S. Nordholt dan G. van Klinken. Jakarta: Yayasan Obor Indonesia. 
Tim Redaksi. 2007. "Situasi Sosial Politik di Wilayah Kepala Burung Provinsi Papua Barat, Inisiatif Perlawanan Lokal Simpul Kepala Burung Papua." Prakarsa Rakyat, edisi Januari-Maret 2007.

Tsing, Anna Lowenhaupt. 2005. Friction: An Ethnography of Global Connection. Princeton: Princeton University Press.

Widjojo, Muridan. 2001. Diantara Kebutuhan Demokrasi dan Kemenangan Kekerasan:
Konflik Papua Pasca Orde Baru. Jakarta: LP3ES dan The Ford Foundation.

Zollner, Zilfred. 2006. Hak-hak Ekonomi, Sosial dan Budaya di Papua Barat: Studi Realita Sosial dan Perspektif Politis. Jakarta: Pustaka Sinar Harapan bekerjasama dengan The Evangelical Church in the Rhineland dan Gereja Kristen Injili di Tanah Papua. 